\title{
Re-evaluation of the pathogenic roles of nonstructural protein 1 and its antibodies during dengue virus infection
}

\author{
Yung-Chun Chuang ${ }^{1}$, Shu-Ying Wang ${ }^{1,2}$, Yee-Shin Lin ${ }^{1,2}$, Hong-Ru Chen ${ }^{1,3}$ and Trai-Ming Yeh ${ }^{1,4^{*}}$
}

\begin{abstract}
Dengue virus (DENV) infection can cause life-threatening dengue hemorrhagic fever (DHF) and dengue shock syndrome (DSS). Vascular leakage and abnormal hemorrhage are the two major pathogenic changes found in these patients. From previous studies, it is known that both antibodies and cytokines induced in response to DENV infection are involved in the immunopathogenesis of DHF/DSS. However, the role of viral factors during DENV infection remains unclear. Nonstructural protein 1 (NS1), which is secreted in the sera of patients, is a useful diagnostic marker for acute DENV infection. Nevertheless, the roles of NS1 and its antibodies in the pathogenesis of DHF/DSS are unclear. The focus of this review is to evaluate the possible contributions of NS1 and the antibodies it induces to vascular leakage and abnormal hemorrhage during DENV infection, which may provide clues to better understanding the pathogenesis of DHF/DSS.
\end{abstract}

Keywords: Endothelium, Permeability, Hemorrhage, Pathogenesis

\section{Review \\ Introduction}

Dengue virus (DENV) belongs to the genus flavivirus and is a positive-stranded enveloped RNA virus. The RNA is approximately $10.1 \mathrm{~Kb}$ and is translated into three structural proteins: core protein $(C)$, membraneassociated protein $(\mathrm{M})$ produced as a precursor protein (prM) and envelope protein (E). Additionally, there are 7 nonstructural proteins (NS), including NS1, NS2a, NS2b, NS3, NS4a, NS4b and NS5. Based on the antigenic differences of the E protein, DENV can be subgrouped into four different serotypes: DENV 1, 2, 3, and 4 [1-3].

DENV infection is transmitted by Aedes mosquitoes. It is prevalent in tropic and sub-tropic areas where the vector resides. It has been estimated that greater than 2.5 billion people live in endemic areas, and the number of individuals infected by DENV is thought to exceed 50 million globally per year $[4,5]$. Most DENV infections cause

\footnotetext{
* Correspondence: today@mail.ncku.edu.tw

${ }^{1}$ Center of Infectious Disease and Signaling Research, Medical College,

National Cheng Kung University, Tainan, Taiwan

${ }^{4}$ Department of Medical Laboratory Science and Biotechnology, Medical

College, National Cheng Kung University, Tainan, Taiwan

Full list of author information is available at the end of the article
}

flu-like symptoms, such as fever, headache, muscle and bone pain. This infection is referred to as dengue fever (DF), and it naturally resolves in several days. However, in some patients, severe dengue hemorrhagic fever/dengue shock syndrome (DHF/DSS) may occur. This is correlated with high viremia, secondary dengue virus infection, and DENV type 2 [6-8]. The characteristic features of DHF/ DSS include vascular (plasma) leakage, thrombocytopenia, and coagulopathy. Due to a lack of knowledge regarding the process leading to DHF/DSS, only supportive treatment is currently available [9]. In addition, vector control is the only method of prevention, as there is no effective vaccine currently available for DENV [10]. Therefore, further study of the host and viral factors of dengue pathogenesis is crucial for developing effective vaccines and drugs to prevent the occurrence of DHF/DSS $[11,12]$.

Flavivirus NS1 is a relatively conserved glycoprotein with a molecular weight of $46-55 \mathrm{kDa}$, depending on its glycosylation status, which exists in different forms at different cellular locations [13]. Immature NS1 exists as a monomer in the endoplasmic reticulum, and it is processed into a stable homodimer that can be covalently linked to the surface membrane via a glycosylphosphatidylinositol anchor [14]. Mature DENV NS1 
contains 352 amino acid residues with two N-linked glycosylation sites at residues 130 and 207. There are 12 cysteine residues in DENV NS1 that are absolutely conserved among all flavivirus NS1 proteins, indicating the importance of disulfide bonds in the structure and function of NS1 (Figure 1) [15]. Unlike other nonstructural proteins, DENV NS1 can also be secreted as a soluble hexamer, which forms a lipoprotein particle with an open-barrel protein shell and a prominent central channel rich in lipids $[16,17]$. NS1 antigen circulates in dengue patients from the first day after the onset of fever up to day 9 , when the clinical phase of the disease is over [18]. The serum levels of NS1 are estimated to range from 0.01 to $50 \mu \mathrm{g} / \mathrm{ml}$ and early concentrations of NS1 in blood are positively associated with disease severity [19]. Therefore, DENV NS1 antigen detection has been successfully used for the early diagnosis of DENV infection [20,21].

Despite the many gaps in our knowledge of the structure and function of flavivirus NS1, it is known that intracellular NS1 co-localizes with dsRNA and other components of replication complexes and plays an essential cofactor role in virus replication $[13,23,24]$. Conversely, secreted NS1 has been shown to bind a number of different complement pathway components [25]. Complement activation mediated by DENV NS1, which leads to local and systemic generation of anaphylatoxins and the membrane attack complex, may contribute to the pathogenesis of the vascular leakage that occurs in DHF/DSS patients [26]. In fact, reduction in the levels of complement components have been described in DHF/ DSS patients, suggesting that complement activation may have a role in the pathogenesis of severe disease [27]. In addition, both secreted and membrane-associated DENV NS1 are highly immunogenic, and the antibodies they elicit can cross-react with human endothelial cells and platelets $[28,29]$. Therefore, both NS1 and its antibodies may play pivotal roles in the pathogenesis of DHF/DSS.

\section{Pathogenesis of vascular leakage in DHF/DSS}

The most prominent feature of DHF/DSS and the best indicator of disease severity is plasma leakage [30,31]. Plasma leakage is caused by an increase in the capillary permeability, and it manifests as any combination of hemoconcentration, plural effusion, or ascites. It usually becomes evident on days 3-7 of illness, at which point dengue fever resolves (defervescence), the viral titer drops, and anti-DENV antibodies gradually increase. However, the underlying pathophysiological mechanisms of plasma leakage in DHF/DSS are not fully understood.

It is known that the vascular endothelium plays important roles in the regulation of tissue fluid homeostasis and transmigration of leukocytes [34,35]. Endothelial cells and their associated structures, such as the glycocalyx and basement membrane, form the primary semipermeable barrier, which is tightly regulated in the resting state. During inflammation, the tight junction between adjacent endothelial cells and the surface glycocalyx of the endothelium are acutely or permanently modified as a part of the immune response [36,37]. Thus, vascular permeability is increased, followed by leukocyte adherence and coagulation activation. Although there are differences in the endothelial cell architecture in capillaries of different organs,

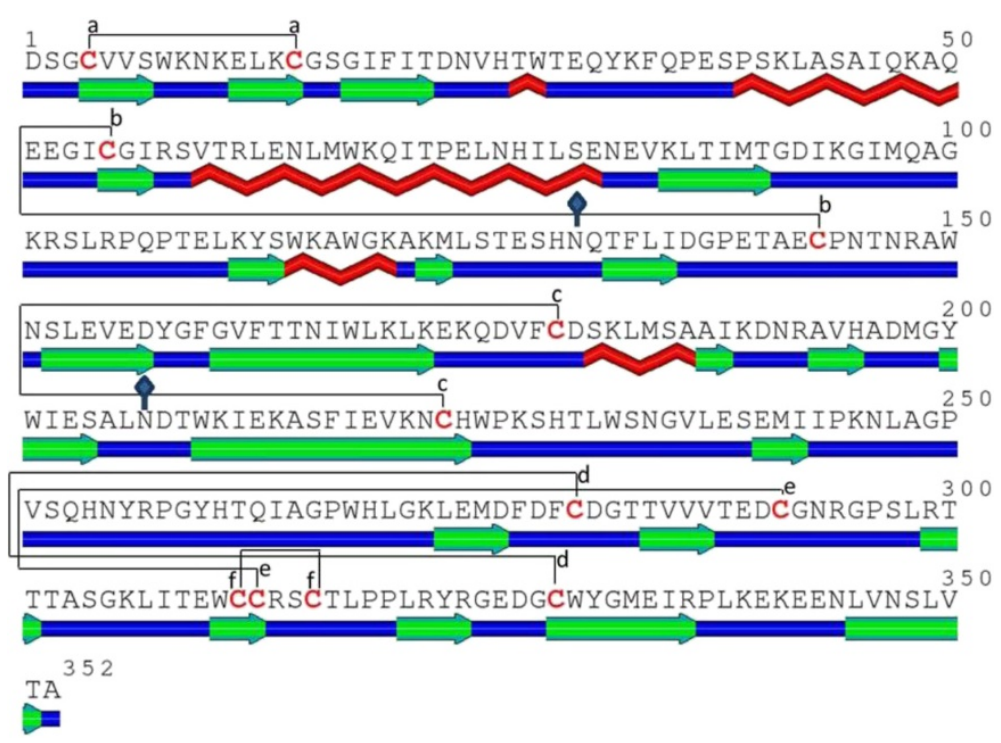

Figure 1 Amino acid sequence and secondary structure of DENV type 2 NS1 protein predicted by SABLE [22]. The elements are color coded as follows: red, a-helix; green, $\beta$-sheet; blue, coil. Linkages of six disulfide bonds (a-f) are represented with solid lines. Two potential $\mathrm{N}$-glycosylation sites are represented with solid diamonds. 




the phenotypic changes associated with endothelial hyperpermeability are similar.

Evidence for endothelial cell activation during DENV infection has been reported [38,39]. Electron microscopy studies have shown vacuolation of the cytoplasm of endothelial cells and gap formations in the endothelial junctions of skin biopsies of DHF patients. Although DENV has been shown to infect endothelial cells in vitro [40], histological studies on viral antigens in tissue specimens suggest that direct infection of endothelial cells by DENV occurs only occasionally $[41,42]$. Nevertheless, many pro-inflammatory cytokines, such as tumor necrosis factor- $\alpha$ (TNF- $\alpha$ ), macrophage migration inhibitory factor (MIF), monocyte chemotactic protein-1 (MCP-1), interleukin-8 (IL-8), and high mobility group box-1 (HMGB-1) are increased during DENV infection, which may contribute to vascular hyperpermeability through the disruption of the tight junction and glycocalyx degradation [33,43-46]. Because pathogenic changes of plasma leakage are reversible, it is generally believed that physical damage is not involved. Instead, soluble mediators, such as cytokines produced during the acute phase of infection, likely play an important role in the pathogenesis of DHF/DSS $[47,48]$. However, it is difficult to reconcile the specific vascular leakage in DENV infection with cytokines or similar bio-active mediators because they are also generated during other infections that do not lead to vascular leakage. Therefore, a more complex interaction between host and virus factors has yet to be characterized in the pathogenesis of vascular leakage in DHF/DSS.

\section{Pathogenesis of thrombocytopenia and coagulopathy in DHF/DSS}

In addition to vascular leakage, almost all DHF patients have abnormal hemostasis, which is evidenced by marked

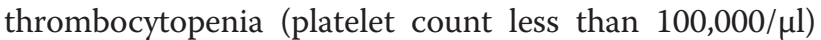
[49]. In fact, thrombocytopenia is one of the most consistent clinical features of severe dengue infection [50]. This occurs as a result of both decrease of platelet production due to DENV-induced bone marrow suppression and increase of platelet destruction in blood circulation [51,52]. Immune complexes containing dengue antigen have been reported on platelet surfaces and may be one of the mechanisms underlying increased platelet destruction [53,54]. Subsequent studies have shown that autoantibodies that can cross-react with platelets are induced in DENV patients and NS1 immunized mice [55,56]. These antiplatelet antibodies may represent another possible mechanism by which platelet consumption is increased during DENV infection.

In addition to thrombocytopenia, an association between coagulation and fibrinolysis activation and clinical outcome is also conceivable $[57,58]$. Prolonged prothrombin time and activated partial thromboplastin time (APTT), reduced fibrinogen level, and increased fibrinogen degradation products are more common in DHF than DF $[59,60]$. Normally, hemostasis is tightly controlled to prevent overt bleeding or thrombosis. Thus far, it remains unclear how hemorrhage is induced during DENV infection. However, autoantibodies and cytokines induced by DENV infection, hemostatic molecules expressed on DENV-infected cells, and DENV viral proteins may all contribute to the defect of hemostasis during DENV infection [61]. The combination of these viral and host factors may tilt the balance of coagulation and fibrinolysis toward bleeding in dengue patients.

\section{Possible pathogenic effects of anti-NS1 cross-reactive antibodies during DENV infection}

Several hypotheses have been proposed to explain the pathogenesis of DHF/DSSincluding antibody-dependent enhancement (ADE) [52]. The ADE hypothesis was proposed to explain why DHF/DSS occurs more commonly in secondary-infected patients with a different serotype of DENV. According to ADE, antibodies against DENV structural proteins, such as E protein or prM, which are generated from previous infections, cannot efficiently neutralize subsequent DENV infections of a different serotype. Rather, these antibodies could bind to DENV andenhance its infection to $\mathrm{Fc} \gamma$ receptor-positive cells such as macrophage [62]. The ADE hypothesis leads us to realize the potential pathogenic roles of antibody in dengue pathogenesis and explains why passive and actively acquired dengue antibodies may result in enhance infections. However, the pathogenic mechanisms of vascular 


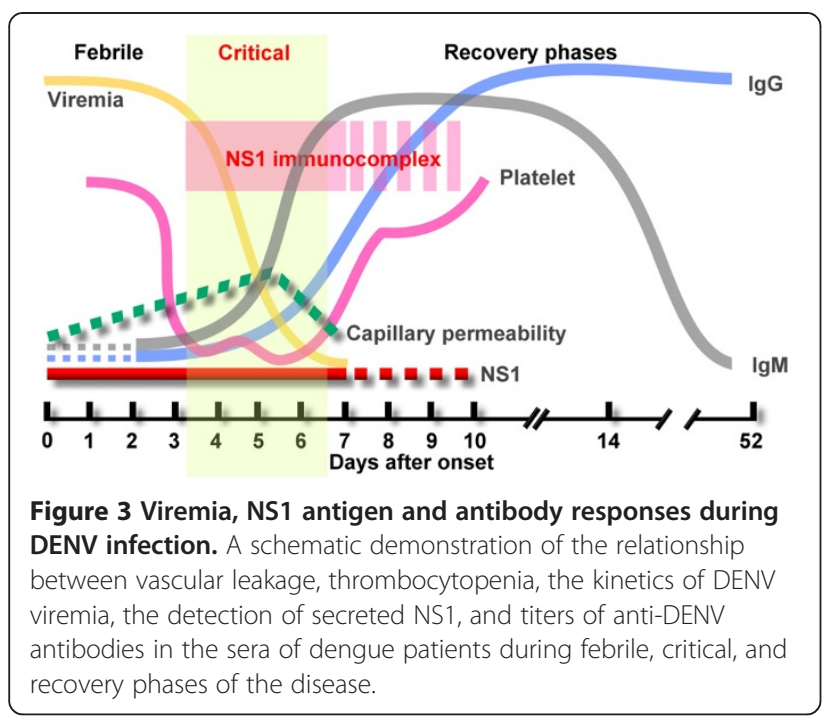

leakage and hemorrhage in DHF/DSS patients are still unclear. Recently, anti-NS1 antibodies that can cross-react with different coagulation-related molecules and cells, such as human plasminogen, thrombin, platelets and endothelial cells, have been reported [63-67]. The titers of these endothelial cells and platelets cross-reactive anti-NS1 antibodies were higher in the acute phaseof DHF/DSS patientsthan those in DF patients. In addition, the titers of these autoantibodies are decreased in the sera collected in the convalescent phase, even though the total anti-NS1 antibody levels continually remain high $[55,68]$. This may explain why there is no subsequent autoimmune disease in DHF patients once they are recovered. These anti-NS1 autoantibodies can lead to thrombocytopenia in vivo $[56,69]$ and nitric oxide-mediated apoptosis of endothelial cells in vitro [64]. Because there is sequence homology between DENV NS1 and proteins on endothelial cells and platelets, it is possible that these autoantibodies are induced by NS1 through molecular mimicry [70]. Therefore, autoantibodies induced by NS1 may contribute to thrombocytopenia, coagulopathy and vascular leakage in DHF/DSS. However, these symptoms in DHF/DSSpatients usually occur within the first week of fever onset when antibodies are still underdeveloped $[7,31,71]$. Therefore, we think the pathogenic roles of secreted NS1 cannot be neglected, especially in the early stage of DENV infection.

\section{Possible pathogenic effects of NS1 during DENV infection} NS1, which is secreted early during DENV infection, can bind to heparan sulfate on the surface of a wide variety of cells, including epithelial cells, fibroblasts, hepatocytes and some endothelial cells [72]. The binding of NS1 to the surface of endothelial cells can induce complement activation, which may contribute to the pathogenesis of vascular leakage that occurs in patients with DHF/DSS [26]. Secreted NS1 can also be endocytosed by hepatocytes, which may enhance DENV infection [73]. Binding of anti-NS1 antibodies to membrane-anchored NS1 can also induce signal transduction, leading to protein tyrosine

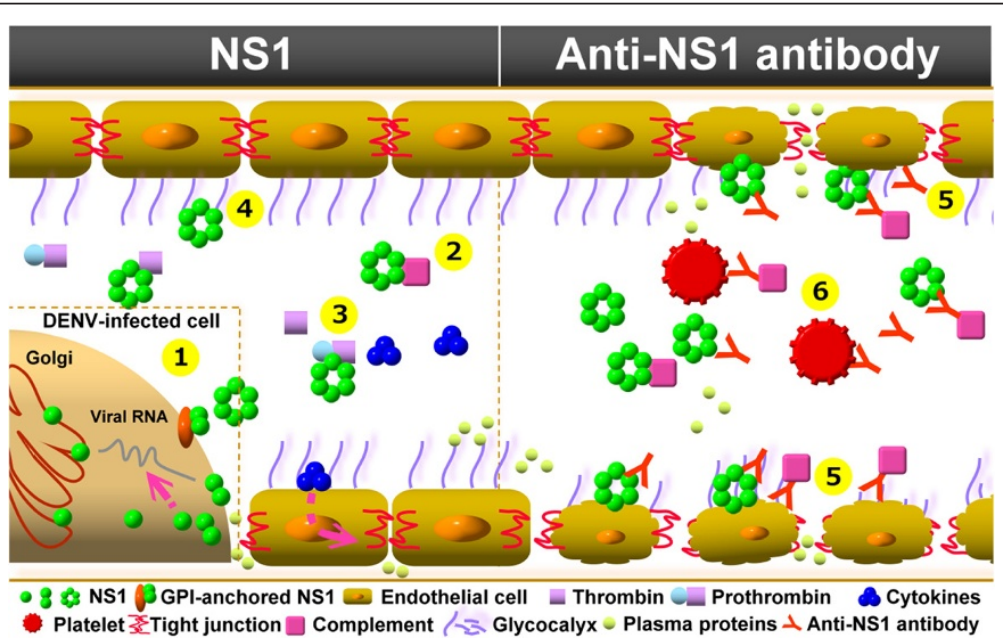

Figure 4 Potential pathogenic roles of NS1 and its antibodies in DENV infection. During DENV infection, NS1 can exist in monomeric, dimeric, or hexameric form. In the left panel, (1) NS1 is involved in DENV replication within cells [13,23,24]. The NS1 dimer can be anchored at the cell membrane, which may be involved in signaling transduction [14]. (2) NS1 can bind to C4 protein and promotes its degradation [74]. (3) NS1 can also bind to prothrombin and inhibit its activation [32]. (4) The binding of NS1 to cells may enhance endocytosis and cytokine production, which may enhance DENV infection and increase vascular permeability [73]. In the right panel, (5) anti-NS1 antibodies that cross-react with endothelial cells may induce endothelial damage [64]. (6) Anti-platelet antibodies elicited by NS1 may inhibit platelet aggregation and cause thrombocytopenia [56]. It is the integrated effects of NS1 and its antibodies, and the immunocomplexes they formed that may contribute to the development of thrombocytopenia, vascular leakage, and coagulopathy during the critical phase of DHF/DSS. 
phosphorylation that might affect DENV replication within infected cells [14]. Conversely, NS1 interacting with complement protein $\mathrm{C} 4$ and $\mathrm{C} 4 \mathrm{~b}$-binding protein, which can promote $\mathrm{C} 4$ degradation, may in turn protect DENV from complement-dependent lysis [74,75]. Therefore, NS1 is a viral factor that can enhance both DENV replication and immune evasion.

Recently, we have demonstrated that DENV NS1 can bind to prothrombin and inhibit its activation, which may prolong APTT in dengue patients [32]. This may explain why APTT abnormality occurs within the first week of fever onset when the antibody response is still weak. In addition, because the vascular leakage in dengue patients is directly correlated with APTT levels, NS1 may also contribute to plasma leakage by mechanisms that do not involve antibodies. In our preliminary study using recombinant DENV NS1 (rNS1) to stimulate the human endothelial cell line HMEC-1, we found that rNS1 stimulation of HMEC-1 cells increased cell permeability in a time-dependent manner, which was positively correlated with the secretion of MIF in the culture medium (Figure 2). Even though further studies using native forms of NS1 are required to confirm the effect of NS1 on the permeability of endothelial cells, it is possible that NS1 may induce cytokine production, such as MIF, to cause vascular leakage in the early stages of DENV infection. NS1 can be detected early during the disease before antibodies are induced, and the levels of NS1 rapidly decrease in the circulation once anti-NS1 antibodies increase [18]. Therefore, peak NS1 is only observed early during the acute phase of infection. As a consequence, the high levels of NS1 do not coincide with the onset of severe disease [19]. In addition, the magnitude of NS1 secretion does not correlate with severe pathology in the mouse model [76]. Thus, we propose that the pathogenic effect of DENV infection on vascular permeability may reach the peak when anti-NS1 antibodies are induced and NS1 immunocomplexes are formed. Besides to the pathogenic effects of NS1 and its antibodies which were mentioned above, complement activation by NS1 immunocomplexesmay further contribute to the development of thrombocytopenia and vascular leakage during the critical phase of DHF/DSS (Figure 3).

\section{Conclusions}

Not only is vascular leakage the hallmark of DHF/DSS, but there is evidence to suggest that damage during DENV infection may begin at endothelial surfaces. In clinical practice, plasma leakage-induced shock-related pathophysiological conditions are most often caused by bacterial infections such as sepsis or septic shock [77]. Regardless of the different causes, similar pathological changes are found in these patients. These are characterized by a systemic inflammatory response causing vascular hyperpermeability and leading to almost uncontrollable edema, coagulation changes and multi-organ failure. Bacterial cell wall components, such as lipopolysaccharide (LPS, or endotoxin), can induce septic shock. However, the viral factors in DHF/ DSS remain unknown. Although it is premature to extrapolate from in vitro findings to human pathogenesis, it is possible that dengue NS1 may play a role similar to LPS for endotoxic shock patients to trigger the pathophysiological abnormalities in DHF/DSS [78]. However, it is the integrated effects of NS1, its antibodies, and the immunocomplexes they formed that may contribute to severe disease outcome (Figure 4). Further studies to investigate the pathogenic roles of NS1 and its antibodies, and of course the contribution of their interaction, immunocomplexes to the overall disease process may improve our current understanding of the pathogenesis of DHF/DSS and uncover new vaccine strategies and therapeutic approaches.

\section{Abbreviations}

ADE: Antibody-dependent enhancement; APTT: Activated partial thromboplastin time; DENV: Dengue virus; DHF: Dengue hemorrhagic fever; DSS: Dengue shock syndrome; NS1: Nonstructural protein 1;

LPS: Lipopolysaccharide.

\section{Competing interests}

These authors declare no competing conflict.

\section{Authors' contributions}

YSL and TMY discussed and designed the concept. YCC, SYW, HRC, and TMY collected information and prepared the manuscript and figures. TMY wrote the manuscript. All the authors read and approved the final manuscript.

\section{Acknowledgements}

This work was supported by a grant from the National Science Council of Taiwan [NSC-101-2321-B-039-009-MY3]. We thank Michael M. C. Lai for help in the revision of this manuscript.

\section{Author details}

'Center of Infectious Disease and Signaling Research, Medical College, National Cheng Kung University, Tainan, Taiwan. ${ }^{2}$ Department of Microbiology and Immunology, Medical College, National Cheng Kung University, Tainan, Taiwan. ${ }^{3}$ Institute of Basic Medical Sciences, Medical College, National Cheng Kung University, Tainan, Taiwan. ${ }^{4}$ Department of Medical Laboratory Science and Biotechnology, Medical College, National Cheng Kung University, Tainan, Taiwan.

Received: 23 March 2013 Accepted: 18 June 2013

Published: 27 June 2013

\section{References}

1. Gubler DJ: Dengue/dengue haemorrhagic fever: history and current status. Novartis Found Symp 2006, 277:3-16. discussion 16-22, 71-73, 251-253.

2. Henchal EA, Putnak JR: The dengue viruses. Clin Microbiol Rev 1990, 3:376-396.

3. Guzman MG, Halstead SB, Artsob H, Buchy P, Farrar J, Gubler DJ, Hunsperger E, Kroeger A, Margolis HS, Martinez E, et al: Dengue: a continuing global threat. Nat Rev Microbiol 2010, 8:S7-S16.

4. Pinheiro FP, Corber SJ: Global situation of dengue and dengue haemorrhagic fever, and its emergence in the Americas. World Health Stat Q 1997, 50:161-169.

5. Kyle JL, Harris E: Global spread and persistence of dengue. Annu Rev Microbiol 2008, 62:71-92.

6. Guzman MG, Kouri G: Dengue: an update. Lancet Infect Dis 2002, 2:33-42.

7. Simmons CP, Farrar JJ, Nguyen vV, Wills B: Dengue. N Engl J Med 2012, 366:1423-1432. 
8. Vaughn DW, Green S, Kalayanarooj S, Innis BL, Nimmannitya S, Suntayakorn S, Endy TP, Raengsakulrach B, Rothman AL, Ennis FA, Nisalak A: Dengue viremia titer, antibody response pattern, and virus serotype correlate with disease severity. J Infect Dis 2000, 181:2-9.

9. Ngo NT, Cao XT, Kneen R, Wills B, Nguyen VM, Nguyen TQ, Chu VT, Nguyen $\Pi$, Simpson JA, Solomon T, et al: Acute management of dengue shock syndrome: a randomized double-blind comparison of 4 intravenous fluid regimens in the first hour. Clin Infect Dis 2001, 32:204-213.

10. Halstead SB: Dengue vaccine development: a 75\% solution? Lancet 2012, 380:1535-1536.

11. Herrero LJ, Zakhary A, Gahan ME, Nelson MA, Herring BL, Hapel AJ, Keller PA, Obeysekera M, Chen W, Sheng KC, et al: Dengue virus therapeutic intervention strategies based on viral, vector and host factors involved in disease pathogenesis. Pharmacol Ther 2013, 137:266-282.

12. Whitehorn J, Farrar J: Dengue. Br Med Bull 2010, 95:161-173.

13. Muller DA, Young PR: The flavivirus NS1 protein: molecular and structural biology, immunology, role in pathogenesis and application as a diagnostic biomarker. Antiviral Res 2013, 98:192-208.

14. Jacobs MG, Robinson PJ, Bletchly C, Mackenzie JM, Young PR: Dengue virus nonstructural protein 1 is expressed in a glycosyl-phosphatidylinositollinked form that is capable of signal transduction. FASEB J 2000 $14: 1603-1610$

15. Wallis TP, Huang CY, Nimkar SB, Young PR, Gorman JJ: Determination of the disulfide bond arrangement of dengue virus NS1 protein. $J$ Biol Chem 2004, 279:20729-20741.

16. Gutsche I, Coulibaly F, Voss JE, Salmon J, d'Alayer J, Ermonval M, Larquet E, Charneau P, Krey T, Megret F, et al: Secreted dengue virus nonstructural protein NS1 is an atypical barrel-shaped high-density lipoprotein. Proc Natl Acad Sci USA 2011, 108:8003-8008.

17. Flamand M, Megret F, Mathieu M, Lepault J, Rey FA, Deubel V: Dengue virus type 1 nonstructural glycoprotein NS1 is secreted from mammalian cells as a soluble hexamer in a glycosylation-dependent fashion. J Virol 1999, 73:6104-6110

18. Alcon S, Talarmin A, Debruyne M, Falconar A, Deubel V, Flamand M: Enzyme-linked immunosorbent assay specific to dengue virus type 1 nonstructural protein NS1 reveals circulation of the antigen in the blood during the acute phase of disease in patients experiencing primary or secondary infections. J Clin Microbiol 2002, 40:376-381.

19. Libraty DH, Young PR, Pickering D, Endy TP, Kalayanarooj S, Green S, Vaughn DW, Nisalak A, Ennis FA, Rothman AL: High circulating levels of the dengue virus nonstructural protein NS1 early in dengue illness correlate with the development of dengue hemorrhagic fever. J Infect Dis 2002, 186:1165-1168.

20. Young PR, Hilditch PA, Bletchly C, Halloran W: An antigen capture enzymelinked immunosorbent assay reveals high levels of the dengue virus protein NS1 in the sera of infected patients. J Clin Microbiol 2000, 38:1053-1057.

21. Peeling RW, Artsob H, Pelegrino JL, Buchy P, Cardosa MJ, Devi S, Enria DA Farrar J, Gubler DJ, Guzman MG, et al: Evaluation of diagnostic tests: dengue. Nat Rev Microbiol 2010, 8:S30-S38.

22. Adamczak R, Porollo A, Meller J: Combining prediction of secondary structure and solvent accessibility in proteins. Proteins 2005, 59:467-475.

23. Khromykh AA, Sedlak PL, Westaway EG: cis- and trans-acting elements in flavivirus RNA replication. J Virol 2000, 74:3253-3263.

24. Mackenzie JM, Jones MK, Young PR: Immunolocalization of the dengue virus nonstructural glycoprotein NS1 suggests a role in viral RNA replication. Virology 1996, 220:232-240.

25. Kurosu T, Chaichana P, Yamate M, Anantapreecha S, Ikuta K: Secreted complement regulatory protein clusterin interacts with dengue virus nonstructural protein 1. Biochem Biophys Res Commun 2007, 362:1051-1056.

26. Avirutnan $\mathrm{P}$, Punyadee $\mathrm{N}$, Noisakran $\mathrm{S}$, Komoltri $\mathrm{C}$, Thiemmeca $\mathrm{S}_{,}$ Auethavornanan K, Jairungsri A, Kanlaya R, Tangthawornchaikul N, Puttikhunt $C$, et al: Vascular leakage in severe dengue virus infections: a potential role for the nonstructural viral protein NS1 and complement. J Infect Dis 2006, 193:1078-1088.

27. Whitehorn J, Simmons CP: The pathogenesis of dengue. Vaccine 2011, 29:7221-7228

28. Lin CF, Wan SW, Cheng HJ, Lei HY, Lin YS: Autoimmune pathogenesis in dengue virus infection. Viral Immunol 2006, 19:127-132.

29. Wan SW, Lin CF, Yeh TM, Liu CC, Liu HS, Wang S, Ling P, Anderson R, Lei HY, Lin YS: Autoimmunity in dengue pathogenesis. J Formos Med Assoc 2013, 112:3-11.
30. Srikiatkhachorn A: Plasma leakage in dengue haemorrhagic fever. Thromb Haemostasis 2009, 102:1042-1049.

31. Trung DT, Wills B: Systemic vascular leakage associated with dengue infections - the clinical perspective. Curr Top Microbiol Immunol 2010, 338:57-66.

32. Lin SW, Chuang YC, Lin YS, Lei HY, Liu HS, Yeh TM: Dengue virus nonstructural protein NS1 binds to prothrombin/thrombin and inhibits prothrombin activation. J Infect 2012, 64:325-334.

33. Chuang YC, Lei HY, Liu HS, Lin YS, Fu TF, Yeh TM: Macrophage migration inhibitory factor induced by dengue virus infection increases vascular permeability. Cytokine 2011, 54:222-231.

34. Ait-Oufella H, Maury E, Lehoux S, Guidet B, Offenstadt G: The endothelium: physiological functions and role in microcirculatory failure during severe sepsis. Intens Care Med 2010, 36:1286-1298.

35. Komarova Y, Malik AB: Regulation of endothelial permeability via paracellular and transcellular transport pathways. Annu Rev Physiol 2010, 72:463-493.

36. Schmidt EP, Yang Y, Janssen WJ, Gandjeva A, Perez MJ, Barthel L, Zemans RL, Bowman JC, Koyanagi DE, Yunt ZX, et al: The pulmonary endothelial glycocalyx regulates neutrophil adhesion and lung injury during experimental sepsis. Nat Med 2012, 18:1217-1223.

37. Curry FR, Noll T: Spotlight on microvascular permeability. Cardiovasc Res 2010, 87:195-197.

38. Sahaphong S, Riengrojpitak S, Bhamarapravati N, Chirachariyavej T: Electron microscopic study of the vascular endothelial cell in dengue hemorrhagic fever. Southeast Asian J Trop Med Public Health 1980, 11:194-204.

39. Sosothikul D, Seksarn P, Pongsewalak S, Thisyakorn U, Lusher J: Activation of endothelial cells, coagulation and fibrinolysis in children with Dengue virus infection. Thromb Haemostasis 2007, 97:627-634.

40. Huang YH, Lei HY, Liu HS, Lin YS, Liu CC, Yeh TM: Dengue virus infects human endothelial cells and induces IL- 6 and IL-8 production. Am J Trop Med Hyg 2000, 63:71-75.

41. Halstead SB: Pathogenesis of dengue: challenges to molecular biology. Science 1988, 239:476-481.

42. Jessie K, Fong MY, Devi S, Lam SK, Wong KT: Localization of dengue virus in naturally infected human tissues, by immunohistochemistry and in situ hybridization. J Infect Dis 2004, 189:1411-1418.

43. Appanna R, Wang SM, Ponnampalavanar SA, Lum LC, Sekaran SD: Cytokine factors present in dengue patient sera induces alterations of junctional proteins in human endothelial cells. Am J Trop Med Hyg 2012, 87:936-942.

44. Ong SP, Lee LM, Leong YF, Ng ML, Chu JJ: Dengue virus infection mediates HMGB1 release from monocytes involving PCAF acetylase complex and induces vascular leakage in endothelial cells. PLOS One 2012, 7:e41932.

45. Dewi BE, Takasaki T, Kurane I: In vitro assessment of human endothelia cell permeability: effects of inflammatory cytokines and dengue virus infection. J Virol Methods 2004, 121:171-180.

46. Lee YR, Liu MT, Lei HY, Liu CC, Wu JM, Tung YC, Lin YS, Yeh TM, Chen SH, Liu HS: MCP-1, a highly expressed chemokine in dengue haemorrhagic fever/dengue shock syndrome patients, may cause permeability change, possibly through reduced tight junctions of vascular endothelium cells. J Gen Virol 2006, 87:3623-3630.

47. Assuncao-Miranda I, Amaral FA, Bozza FA, Fagundes CT, Sousa LP, Souza DG, Pacheco P, Barbosa-Lima G, Gomes RN, Bozza PT, et al: Contribution of macrophage migration inhibitory factor to the pathogenesis of dengue virus infection. FASEB J 2010, 24:218-228.

48. Souza DG, Fagundes $C$, Sousa LP, Amaral FA, Souza RS, Souza AL, Kroon EG, Sachs D, Cunha FQ, Bukin E, et al: Essential role of platelet-activating factor receptor in the pathogenesis of Dengue virus infection. Proc Natl Acad SCi USA 2009, 106:14138-14143.

49. Halstead SB: Dengue: hematologic aspects. Semin Hematol 1982, 19:116-131.

50. Halstead SB: Antibody, macrophages, dengue virus infection, shock, and hemorrhage: a pathogenetic cascade. Rev Infect Dis 1989, 11(Suppl 4):S830-S839.

51. La Russa VF, Innis BL: Mechanisms of dengue virus-induced bone marrow suppression. Baillieres Clin Haematol 1995, 8:249-270.

52. Lei HY, Yeh TM, Liu HS, Lin YS, Chen SH, Liu CC: Immunopathogenesis of dengue virus infection. J Biomed Sci 2001, 8:377-388.

53. Mitrakul C, Poshyachinda M, Futrakul P, Sangkawibha N, Ahandrik S: Hemostatic and platelet kinetic studies in dengue hemorrhagic fever. Am J Trop Med Hyg 1977, 26:975-984. 
54. Phanichyakarn $P$, Israngkura PB, Krisarin C, Pongpanich B, Dhanamitta S, Valyasevi A, Studies on dengue hemorrhagic fever. IV: Fluorescence staining of the immune complexes on platelets. J Med Assoc Thai 1977, 60:307-311.

55. Lin CF, Lei HY, Liu CC, Liu HS, Yeh TM, Wang ST, Yang TI, Sheu FC, Kuo CF, Lin YS: Generation of IgM anti-platelet autoantibody in dengue patients. J Med Virol 2001, 63:143-149.

56. Sun DS, King CC, Huang HS, Shih YL, Lee CC, Tsai WJ, Yu CC, Chang HH: Antiplatelet autoantibodies elicited by dengue virus non-structural protein 1 cause thrombocytopenia and mortality in mice. J Thromb Haemost 2007, 5:2291-2299.

57. Wills BA, Oragui EE, Stephens AC, Daramola OA, Dung NM, Loan HT, Chau NV, Chambers M, Stepniewska K, Farrar JJ, Levin M: Coagulation abnormalities in dengue hemorrhagic fever: serial investigations in 167 Vietnamese children with dengue shock syndrome. Clin Infect Dis 2002, 35:277-285.

58. Mairuhu AT, Mac Gillavry MR, Setiati TE, Soemantri A, ten Cate H, Brandjes DP, van Gorp EC: Is clinical outcome of dengue-virus infections influenced by coagulation and fibrinolysis? A critical review of the evidence. Lancet Infect Dis 2003, 3:33-41.

59. Krishnamurti C, Kalayanarooj S, Cutting MA, Peat RA, Rothwell SW, Reid TJ, Green S, Nisalak A, Endy TP, Vaughn DW, et al: Mechanisms of hemorrhage in dengue without circulatory collapse. Am J Trop Med Hyg 2001, 65:840-847.

60. Huang YH, Liu CC, Wang ST, Lei HY, Liu HL, Lin YS, Wu HL, Yeh TM: Activation of coagulation and fibrinolysis during dengue virus infection. J Med Virol 2001, 63:247-251.

61. Chuang YC, Lin YS, Liu CC, Liu HS, Liao SH, Shi MD, Lei HY, Yeh TM: Factors contributing to the disturbance of coagulation and fibrinolysis in dengue virus infection. J Formos Med Assoc 2013, 112:12-17.

62. Dejnirattisai W, Jumnainsong A, Onsirisakul N, Fitton P, Vasanawathana S, Limpitikul W, Puttikhunt C, Edwards C, Duangchinda T, Supasa S, et al: Cross-reacting antibodies enhance dengue virus infection in humans. Science 2010, 328:745-748.

63. Falconar AK: The dengue virus nonstructural-1 protein (NS1) generates antibodies to common epitopes on human blood clotting, integrin/ adhesin proteins and binds to human endothelial cells: potential implications in haemorrhagic fever pathogenesis. Arch Virol 1997, 142:897-916.

64. Lin CF, Lei HY, Shiau AL, Liu HS, Yeh TM, Chen SH, Liu CC, Chiu SC, Lin YS: Endothelial cell apoptosis induced by antibodies against dengue virus nonstructural protein 1 via production of nitric oxide. J Immunol 2002, 169:657-664.

65. Cheng HJ, Lei HY, Lin CF, Luo YH, Wan SW, Liu HS, Yeh TM, Lin YS: Antidengue virus nonstructural protein 1 antibodies recognize protein disulfide isomerase on platelets and inhibit platelet aggregation. $\mathrm{Mo}$ Immunol 2009, 47:398-406.

66. Chuang YC, Lin YS, Liu HS, Wang JR, Yeh TM: Antibodies against thrombin in dengue patients contain both anti-thrombotic and pro-fibrinolytic activities. Thromb Haemost 2013, 110. in press.

67. Chuang YC, Lei HY, Lin YS, Liu HS, Wu HL, Yeh TM: Dengue virus-induced autoantibodies bind to plasminogen and enhance its activation. J Immunol 2011, 187:6483-6490.

68. Lin CF, Lei HY, Shiau AL, Liu CC, Liu HS, Yeh TM, Chen SH, Lin YS: Antibodies from dengue patient sera cross-react with endothelial cells and induce damage. J Med Virol 2003, 69:82-90.

69. Huang KJ, Li SYJ, Chen SC, Liu HS, Lin YS, Yeh TM, Liu CC, Lei HY: Manifestation of thrombocytopenia in dengue-2-virus-infected mice. $J$ Gen Virol 2000, 81:2177-2182

70. Lin YS, Yeh TM, Lin CF, Wan SW, Chuang YC, Hsu TK, Liu HS, Liu CC, Anderson R, Lei HY: Molecular mimicry between virus and host and its implications for dengue disease pathogenesis. Exp Biol Med (Maywood) 2011, 236:515-523.

71. Wills B, Tran VN, Nguyen TH, Truong TT, Tran TN, Nguyen MD, Tran VD Nguyen W, Dinh T, Farrar J: Hemostatic changes in Vietnamese children with mild dengue correlate with the severity of vascular leakage rather than bleeding. Am J Trop Med Hyg 2009, 81:638-644.

72. Avirutnan P, Zhang L, Punyadee N, Manuyakorn A, Puttikhunt C, Kasinrerk W, Malasit $P$, Atkinson JP, Diamond MS: Secreted NS1 of dengue virus attaches to the surface of cells via interactions with heparan sulfate and chondroitin sulfate E. PLoS Pathog 2007, 3:e183.
73. Alcon-LePoder $S$, Drouet MT, Roux P, Frenkiel MP, Arborio M, Durand-Schneider AM, Maurice M, Le Blanc I, Gruenberg J, Flamand M: The secreted form of dengue virus nonstructural protein NS1 is endocytosed by hepatocytes and accumulates in late endosomes: implications for viral infectivity. J Virol 2005, 79:11403-11411.

74. Avirutnan P, Fuchs A, Hauhart RE, Somnuke P, Youn S, Diamond MS, Atkinson JP: Antagonism of the complement component C4 by flavivirus nonstructural protein NS1. J Exp Med 2010, 207:793-806.

75. Avirutnan P, Hauhart RE, Somnuke P, Blom AM, Diamond MS, Atkinson JP: Binding of flavivirus nonstructural protein NS1 to C4b binding protein modulates complement activation. J Immunol 2011, 187:424-433.

76. Watanabe S, Tan KH, Rathore AP, Rozen-Gagnon K, Shuai W, Ruedl C, Vasudevan SG: The magnitude of dengue virus NS1 protein secretion is strain dependent and does not correlate with severe pathologies in the mouse infection model. J Virol 2012, 86:5508-5514.

77. Lee WL, Slutsky AS: Sepsis and endothelial permeability. N Engl J Med 2010, 363:689-691.

78. Halstead SB: Dengue vascular permeability syndrome: what, no T cells? Clin Infect Dis 2013, 56:900-901.

doi:10.1186/1423-0127-20-42

Cite this article as: Chuang et al:: Re-evaluation of the pathogenic roles of nonstructural protein 1 and its antibodies during dengue virus infection. Journal of Biomedical Science 2013 20:42.

\section{Submit your next manuscript to BioMed Central and take full advantage of:}

- Convenient online submission

- Thorough peer review

- No space constraints or color figure charges

- Immediate publication on acceptance

- Inclusion in PubMed, CAS, Scopus and Google Scholar

- Research which is freely available for redistribution 